\title{
Effect of farm yard manure, phosphorus and sulphur on yield parameters, yield, nodulation, nutrient uptake and quality of chickpea (Cicer arietinum L.)
}

\author{
S. K. Das*, B. Biswas and K. Jana \\ Directorate of Research, Bidhan Chandra Krishi Viswavidyalaya, Kalyani-741235 Nadia (West Bengal), INDIA \\ *Corresponding author. E-mail: sanjibag@gmail.com
}

Received: July 24, 2015; Revised received: January 1, 2016; Accepted: April 4, 2016

\begin{abstract}
Field experiments were conducted for three years at Pulses and Oilseeds Research Station, Berhampore, Murshidabad, West Bengal, India during rabi 2010-11, 2011-12 and 2012-13 to study the effects of farm yard manure (FYM), phosphorus and sulphur on yield parameters, yield, nodulation, nutrient uptake and quality of chickpea. The experiment was laid out in a factorial randomized block design with three replications having twelve treatment combinations viz. two levels of $F Y M\left(F_{0}-0 t\right.$ ha ${ }^{-1}, F_{1}-5 t$ ha $\left.{ }^{-1}\right)$ as factor $A$, three levels of phosphorus $\left(P_{0}-0\right.$ $\left.\mathrm{kg} \mathrm{ha}^{-1}, \mathrm{P}_{30}-30 \mathrm{~kg} \mathrm{ha}^{-1}, \mathrm{P}_{60}-60 \mathrm{~kg} \mathrm{ha}^{-1}\right)$ as factor $B$ and two levels of sulphur $\left(\mathrm{S}_{0}-0 \mathrm{~kg} \mathrm{ha}^{-1}, \mathrm{~S}_{20}-20 \mathrm{~kg} \mathrm{ha}^{-1}\right)$ as factor C. Experimental results revealed that yield attributing characters, yield and protein content of chickpea were significantly influenced by FYM, phosphorus, sulphur and interaction effects of these three factors. Significantly

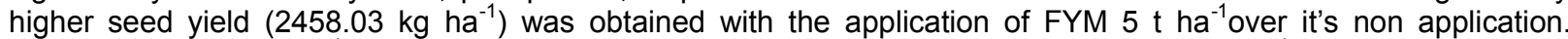
Application of $60 \mathrm{~kg} \mathrm{ha}^{-1}$ phosphorus recorded significantly higher seed yield $\left(2735.50 \mathrm{~kg} \mathrm{ha}^{-1}\right)$ of chickpea cultivar Anuradha. Application of $20 \mathrm{~kg} \mathrm{ha}^{-1}$ sulphur recorded significantly higher seed yield $\left(2532.32 \mathrm{~kg} \mathrm{ha}^{-1}\right)$ over it's non application in a sulphur deficient soil. Among the interaction effects application of $60 \mathrm{~kg} \mathrm{ha}^{-1}$ phosphorus and $20 \mathrm{~kg}$ $\mathrm{ha}^{-1}$ sulphur in Farm yard manure $\left(5 \mathrm{t} \mathrm{ha}^{-1}\right)$ treated plot recorded highest seed yield $\left(2979.3 \mathrm{~kg} \mathrm{ha}^{-1}\right)$. Application of sulphur $20 \mathrm{~kg} \mathrm{ha}^{-1}$ increased the nodule no. by $14.4 \%$. Application of $60 \mathrm{~kg} \mathrm{ha}^{-1}$ phosphorus and $20 \mathrm{~kg} \mathrm{ha}^{-1} \mathrm{sulphur}$ in Farm yard manure treated plot $\left(5 \mathrm{t} \mathrm{ha}^{-1}\right)$ increased the nodule no. by $62.3 \%$. Varying levels of phosphorus along with sulphur and FYM significantly improved the nutrient uptake by chickpea in a sulphur deficient soil. Application of $60 \mathrm{~kg} \mathrm{ha}^{-1}$ phosphorus and $20 \mathrm{~kg} \mathrm{ha}^{-1}$ sulphur in Farm yard manure treated plot $\left(5 \mathrm{t} \mathrm{ha}^{-1}\right)$ along with recommended dose of nitrogen and potassium proved to be the best treatment combination for increasing the productivity of chickpea and thereby increasing the pulse production of the country.
\end{abstract}

Keywords: Chickpea, FYM, Nodulation, Nutrient uptake, Phosphorus, Seed yield, Sulphur

\section{INTRODUCTION}

With the growing population of the world in general and the developing countries in particular, demands are overwhelmed for enhanced food production. Various pulses play an important role to satisfy the growing human food demands and nutritional security. Among many others, chickpea is an important source of protein rich food for the people especially in the subcontinent. Chickpea is the second most important pulse crop in the world. Productivity of this crop is much below than the national average, and the prime factor is the non-judicious use of fertilizers. Legumes generally require higher amount of phosphorus as the process of symbiotic nitrogen fixation consumes a lot of energy (Schulze et al., 2006). Apart from being a constituent of certain malic acids, phosphorus stimulates root, seed and fruit development as well as aids in vital metabolic functions (Singh et al., 2012). Now-a-days soil health has become a cause of concern for sustainable agricultural production in the new millennium. Use of high analysis fertilizers, less use of organic manures, heavy sulphur (S) removal by the crops under intensive cultivation \& neglect of $S$ replenishment contributed to widespread $\mathrm{S}$ deficiencies in India. Sulphur deficiencies have been reported from 72 countries in the world (Morris, 1998). Over 27000 soil samples from twelve states of India were analysed of which $40 \%$ were found deficient \& another $35 \%$ were potentially deficient in available sulphur (Biswas et al., 2004). More than $70 \%$ soil samples taken from U.P., M.P., Maharastra, Orissa, Jharkhand, West Bengal, Andhra Pradesh and Karnataka were found low to medium in available sulphur. In West Bengal sulphur deficiency has been observed in $67 \%$ samples in red \& lateritic soils of Midnapur \& $63 \%$ in Gangetic alluviums of Nadia district (Biswas et al., 2004). Three soil series which were non deficient in sulphur are located in rainfed, monocropped coastal saline zone of W.B. (Ghosh et al., 2002). Sulphur has a great role in Nfixation by influencing active nodulation in legume. It is a part of nitrogenase enzyme, promotes nodulation in legumes, which enhances biological $\mathrm{N}$-fixation (BNF) and the productivity of pulses may drastically 
be reduced by an inadequate supply of sulphur. It is also necessary for chlorophyll formation and helps in biosynthesis of oil and metabolism of carbohydrates, proteins and fats and thus now-a-days sulphur is being considered as the fourth major nutrient element after NPK. An adequate supply of mineral nutrients to legumes enhances nitrogen fixation (Ganeshamurthy and Reddy, 2000). For example, starter N stimulated early seedling growth and nodulation (Daramola et al., 1982); Phosphorus and sulphur improve nodulation activity (Olivera et al., 2004; Scherer et al., 2008). Sulphur deficiency decreases the concentration of $\mathrm{N}$ in the shoots and seeds of many legumes (Claro-Cortes et al., 2002). There is direct involvement of sulfur in the process of nitrogen fixation whereas effect of phosphorus on nitrogen fixation is indirect mainly through enhanced growth and dry matter production. Keeping the above information in view, the present investigation was proposed to be conducted to study the effect of FYM (Farm yard manure) sulphur and phosphorus in chickpea under new alluvial zone of West Bengal.

\section{MATERIALS AND METHODS}

Field experiments were conducted at Pulses and Oilseeds Research Station, Berhampore, Murshidabad, West Bengal, India situated at $24^{\circ} 60^{\prime} \mathrm{N}$ latitude, $88^{\circ} 15^{\prime} \mathrm{E}$ longitude at an elevation of 19.0 meters above the mean sea level (MSL) during rabi 2010-11, 2011-12 and 2012-13. The soil of the experimental field was sandy loam in texture and slightly alkaline in reaction $(\mathrm{pH} 7.5)$ having an organic carbon content of $0.31 \%, 71 \mathrm{~kg}$ available $\mathrm{P}_{2} \mathrm{O}_{5} \mathrm{ha}^{-1}$, $113 \mathrm{~kg}$ available $\mathrm{K}_{2} \mathrm{O} \mathrm{ha}^{-1}$ and $8.1 \mathrm{~kg}$ available $\mathrm{S} \mathrm{ha}^{-1}$. The experiment was laid out in a factorial randomized block design with three replications having twelve treatment combinations viz., two levels of FYM ( $\mathrm{F}_{0}-0 \mathrm{tha}^{-1}, \mathrm{~F}_{1}-5 \mathrm{t}$ $\left.\mathrm{ha}^{-1}\right)$ as factor $\mathrm{A}$, three levels of phosphorus $\left(\mathrm{P}_{0}-0 \mathrm{~kg} \mathrm{ha}^{-1}\right.$, $\left.\mathrm{P}_{30}-30 \mathrm{~kg} \mathrm{ha}^{-1}, \mathrm{P}_{60}-60 \mathrm{~kg} \mathrm{ha}^{-1}\right)$ as factor $\mathrm{B}$ and two levels of sulphur $\left(\mathrm{S}_{0}-0 \mathrm{~kg} \mathrm{ha}^{-1}, \mathrm{~S}_{20}-20 \mathrm{~kg} \mathrm{ha}^{-1}\right)$ as factor $\mathrm{C}$ with a plot size of $4 \mathrm{~m} \mathrm{X} 3 \mathrm{~m}$. The crop was sown on first week of December, 2010-11, 2011-12 and 2012-13 respectively. The chickpea variety used was Anuradha (B-392) and the seed rate was $50 \mathrm{~kg}$ per ha. with a spacing of $30 \mathrm{~cm}$ X $10 \mathrm{~cm}$. Nitrogen was applied at the rate $23.5 \mathrm{~kg}$ $\mathrm{ha}^{-1}$ and potassium was applied at the rate $20 \mathrm{~kg} \mathrm{ha}^{-1}$ to all the treatments. Nitrogen was applied through Urea, phosphorus through di- ammonium phosphate, potassium through muriate of potash and $\mathrm{S}$ through elemental sulphur [Field grade $90 \%$ pure] and were applied as basal. Hand weeding was done twice at 20 and 40 days after sowing. Nodulation was studied at $50 \%$ flowering stage. Only active nodules were considered. The nodules with the pink colour of leghaemoglobin were considered active nodules. Nutrient uptake was calculated by multiplying the yield with the concentration of particular nutrient.

Data on yield attributes and seed yield $\left(\mathrm{kg} \mathrm{ha}^{-1}\right)$ were recorded at harvest. Analysis of variance of the data in the experimental design and comparison of means at $\mathrm{p} \leq 0.05$ were carried out, using MSTAT-C software.

\section{RESULTS AND DISCUSSION}

Effect on yield attributing characters and seed yield: Experimental results revealed that yield attributing characters such as primary branches plant ${ }^{-1}$, pods plant $^{-1}$, 100 seed weight of chickpea were significantly influenced by application of FYM, phosphorus (P), sulphur (S) and interaction of FYM , P and S (Tables 1-4). Application of FYM@ $5 \mathrm{t} \mathrm{ha}^{-1}$ recorded significantly higher seed yield (2458.06 $\left.\mathrm{kg} \mathrm{ha}^{-1}\right)$ mainly attributed to significantly higher no. of primary branches plant ${ }^{-1}$ (7.6 nos.), pods plant $^{-1}$ (30.6 nos.), and 100 seed weight (12.8 g) of chickpea. It improved the seed yield by $8.9 \%$ over it's non application. Patil et al. (2011) also reported that application of FYM@ $5 \mathrm{t} \mathrm{ha}^{-1}$ along with rock phosphate significantly increased the yield of chickpea. Application of phosphorus $60 \mathrm{~kg} \mathrm{ha}^{-1}$ recorded significantly higher seed yield $\left(2735.50 \mathrm{~kg} \mathrm{ha}^{-1}\right)$ mainly due to significantly higher no. of primary branches plant ${ }^{-1}\left(8.1\right.$ nos.), pods plant ${ }^{-1}$ (33.6 nos.), and 100 seed weight ( $13.1 \mathrm{~g})$. It improved the seed yield by $6.8 \%$ over application of phosphorus $30 \mathrm{~kg}$ ha $^{-1}$ and $53.9 \%$ over it's non application. Basir et al. (2008), Dotania et al. (2014) and Das et al. (2015) also reported that grain yield of chickpea increased significantly with increase in phosphorus dose and was recorded maximum at $60 \mathrm{~kg} \mathrm{P} \mathrm{ha}^{-1}$. Application of sulphur $20 \mathrm{~kg}$ $\mathrm{ha}^{-1}$ recorded significantly higher seed yield $(2532.33 \mathrm{~kg}$ $\mathrm{ha}^{-1}$ ) mainly attributed to significantly higher no. of primary branches plant ${ }^{-1}$ (7.9 nos.), pods plant ${ }^{-1}(31.4$ nos.), and 100 seed weight (12.9 g) of chickpea. It improved the seed yield by $16 \%$ over it's non application. Increase in yield due to $\mathrm{S}$ application may be due to the fact that $\mathrm{S}$ is related to photosynthesis of plants. Sulphur application increased rate of photosynthesis due to an increment in protein synthesis and maintenance of high chlorophyll content (Ahmad and Abedin, 2000). Similar results of increased seed yield due to application of $20 \mathrm{~kg} \mathrm{~S} \mathrm{ha}^{-1}$ were found by Srinivasarao et al.(2004) and Patel et al.(2014). In case of interaction effect, application of $60 \mathrm{~kg} \mathrm{ha}^{-1}$ phosphorus and $20 \mathrm{~kg} \mathrm{ha}^{-1}$ sulphur in Farm yard manure treated plot $\left(5 \mathrm{t} \mathrm{ha}^{-1}\right)$ recorded highest yield $\left(2979.3 \mathrm{~kg} \mathrm{ha}^{-1}\right)$ mainly attributed to the highest no. of primary branches plant ${ }^{-1}$ ( 8.9 nos.), pods plant $^{-1}$ (36.5 nos.), and 100 seed weight(13.4 g) followed by application of $60 \mathrm{~kg} \mathrm{ha}^{-1}$ phosphorus and 20 $\mathrm{kg} \mathrm{ha}^{-1}$ sulphur without Farm yard manure $(2834.0 \mathrm{~kg}$ ha $\left.{ }^{1}\right)$. The lowest seed yield (1487.3 $\left.\mathrm{kg} \mathrm{ha}^{-1}\right)$ was recorded in control plot. Similarly Patel et al. (2014) also reported that application of $20 \mathrm{~kg} \mathrm{~S} h a^{-1}$ and $25 \mathrm{~kg} \mathrm{P}^{-1}$ along with PSB recorded highest seed yield of chickpea. Singh et al. (2012) also reported that application of FYM @ $5 \mathrm{t} \mathrm{ha}^{-1}$ along with $40 \mathrm{~kg} \mathrm{P} \mathrm{ha}^{-1}$ gave nhighest yield of kabuli chickpea .

Effect on Protein content: Protein content of chickpea seed was also significantly influenced by application of phosphorus (P), sulphur (S) and interaction of FYM, $\mathrm{P}$ and $\mathrm{S}$ (Tables 1-4). Irrespective of FYM and sulphur, application of $60 \mathrm{~kg} \mathrm{ha}^{-1}$ phosphorus significantly 
Table 1. Effect of FYM on yield attributing characters, seed yield $\left(\mathrm{kgha}^{-1}\right)$, protein content and nodulation in chickpea (Pooled data of 3 years).

\begin{tabular}{|c|c|c|c|c|c|c|c|}
\hline Treatment & $\begin{array}{l}\text { No. of pri- } \\
\text { mary } \\
\text { branches } \\
\text { plant }^{-1}\end{array}$ & $\begin{array}{l}\text { No. of pods } \\
\text { plant }^{-1}\end{array}$ & $\begin{array}{l}\text { Number of } \\
\text { seeds pod }\end{array}$ & $\begin{array}{l}100 \text { seed } \\
\text { weight }(g)\end{array}$ & $\begin{array}{l}\text { Nodule no. } \\
\text { plant }^{-1} \text { (at } \\
\mathbf{5 0 \%} \text { flower- } \\
\text { ing) } \\
\end{array}$ & $\begin{array}{l}\text { Protein } \\
\text { content in } \\
\text { seed }(\%)\end{array}$ & $\begin{array}{l}\text { Seed yield } \\
\left(\mathrm{kg} \mathrm{ha}^{-1}\right)\end{array}$ \\
\hline $\mathrm{F}_{0}$ & 7.3 & 28.2 & 1.6 & 12.5 & 67.4 & 20.1 & 2258.10 \\
\hline $\mathrm{F}_{1}$ & 7.6 & 30.6 & 1.7 & 12.8 & 71.1 & 20.3 & 2458.06 \\
\hline $\operatorname{SEm}( \pm)$ & 0.1 & 0.7 & 0.2 & 0.1 & 1.2 & 0.2 & 33.3 \\
\hline $\mathrm{CD}(\mathrm{P}=0.05)$ & 0.3 & 2.0 & NS & 0.3 & 3.5 & NS & 99.9 \\
\hline
\end{tabular}

Table 2. Effect of phosphorus on yield attributing characters, seed yield $\left(\mathrm{kgha}^{-1}\right)$, protein content and nodulation in chickpea (Pooled data of 3 years).

\begin{tabular}{|c|c|c|c|c|c|c|c|}
\hline Treatment & $\begin{array}{l}\text { No. of pri- } \\
\text { mary } \\
\text { branches } \\
\text { plant }^{-1}\end{array}$ & $\begin{array}{l}\text { No. of pods } \\
\text { plant }^{-1}\end{array}$ & $\begin{array}{l}\text { Number of } \\
\text { seeds pod }^{-1}\end{array}$ & $\begin{array}{l}100 \\
\text { seed } \\
\text { weight }(\mathrm{g})\end{array}$ & $\begin{array}{l}\text { Nodule no. } \\
\text { plant }^{-1} \text { (at } \\
50 \% \text { flower- } \\
\text { ing) }\end{array}$ & $\begin{array}{l}\text { Protein } \\
\text { content in } \\
\text { seed }(\%)\end{array}$ & $\begin{array}{l}\text { Seed yield } \\
\left(\mathrm{kg} \mathrm{ha}^{-1}\right)\end{array}$ \\
\hline$\overline{\mathrm{P}_{0}}$ & 6.7 & 23.2 & 1.5 & 11.9 & 57.4 & 19.6 & 1777.58 \\
\hline $\mathrm{P}_{30}$ & 7.7 & 31.4 & 1.7 & 13.0 & 72.9 & 20.4 & 2561.17 \\
\hline $\mathrm{P}_{60}$ & 8.1 & 33.6 & 1.8 & 13.1 & 77.4 & 20.7 & 2735.50 \\
\hline $\operatorname{SEm}( \pm)$ & 0.2 & 0.7 & 0.2 & 0.1 & 1.5 & 0.3 & 40.8 \\
\hline $\mathrm{CD}(\mathrm{P}=0.05)$ & 0.5 & 2.1 & NS & 0.3 & 4.2 & 0.8 & 122.3 \\
\hline
\end{tabular}

Table 3. Effect of sulphur on yield attributing characters, seed yield $\left(\mathrm{kgha}^{-1}\right)$, protein content and nodulation in chickpea (Pooled data of 3 years).

\begin{tabular}{|c|c|c|c|c|c|c|c|}
\hline Treatment & $\begin{array}{l}\text { No. of pri- } \\
\text { mary } \\
\text { branches }^{-1} \\
\text { plant }^{-1}\end{array}$ & $\begin{array}{l}\text { No. of pods } \\
\text { plant }^{-1}\end{array}$ & $\begin{array}{l}\text { Number of } \\
\text { seeds pod }^{-1}\end{array}$ & $\begin{array}{l}100 \\
\text { seed } \\
\text { weight }(\mathrm{g})\end{array}$ & $\begin{array}{l}\text { Nodule no. } \\
\text { plant }^{-1} \\
\text { (at } 50 \% \text { flow- } \\
\text { ering) }\end{array}$ & $\begin{array}{l}\text { Protein } \\
\text { content in } \\
\text { seed }(\%)\end{array}$ & $\begin{array}{l}\text { Seed yield } \\
\left(\mathrm{kg} \mathrm{ha}^{-1}\right)\end{array}$ \\
\hline$\overline{\mathrm{S}_{0}}$ & 7.0 & 27.3 & 1.6 & 12.5 & 64.6 & 19.9 & 2183.83 \\
\hline $\mathrm{S}_{20}$ & 7.9 & 31.4 & 1.7 & 12.9 & 73.9 & 20.5 & 2532.33 \\
\hline $\operatorname{SEm}( \pm)$ & 0.1 & 0.7 & 0.2 & 0.1 & 1.2 & 0.2 & 33.3 \\
\hline $\mathrm{CD}(\mathrm{P}=0.05)$ & 0.3 & 2.0 & NS & 0.3 & 3.5 & 0.5 & 99.9 \\
\hline
\end{tabular}

Table 4. Interaction effect of FYM, phosphorus and sulphur on yield attributing characters, seed yield $\left(\mathrm{kgha}^{-1}\right)$, protein content and nodulation in chickpea (Pooled data of 3 years).

\begin{tabular}{|c|c|c|c|c|c|c|c|}
\hline Treatment & $\begin{array}{l}\text { No. of pri- } \\
\text { mary } \\
\text { branches } \\
\text { plant }^{-1}\end{array}$ & $\begin{array}{l}\text { No. of pods } \\
\text { plant }^{-1}\end{array}$ & $\begin{array}{l}\text { Number of } \\
\text { seeds pod }^{-1}\end{array}$ & $\begin{array}{l}100 \\
\text { seed } \\
\text { weight }(\mathrm{g})\end{array}$ & $\begin{array}{l}\text { Nodule no. } \\
\text { plant }^{-1} \text { (at } \\
50 \% \text { flower- } \\
\text { ing) } \\
\end{array}$ & $\begin{array}{l}\text { Protein } \\
\text { content in } \\
\text { seed }(\%)\end{array}$ & $\begin{array}{l}\text { Seed yield } \\
\left(\mathrm{kg} \mathrm{ha}^{-1}\right)\end{array}$ \\
\hline $\mathrm{F}_{0} \mathrm{P}_{0} \mathrm{~S}_{0}$ & 6.3 & 20.2 & 1.5 & 11.3 & 51.2 & 19.1 & 1487.3 \\
\hline $\mathrm{F}_{0} \mathrm{P}_{30} \mathrm{~S}_{0}$ & 7.1 & 28.1 & 1.6 & 12.8 & 65.5 & 20.0 & 2305.0 \\
\hline $\mathrm{F}_{0} \mathrm{P}_{60} \mathrm{~S}_{0}$ & 7.4 & 30.8 & 1.7 & 12.9 & 70.1 & 20.3 & 2528.0 \\
\hline $\mathrm{F}_{0} \mathrm{P}_{0} \mathrm{~S}_{20}$ & 6.8 & 23.0 & 1.5 & 12.0 & 59.3 & 19.8 & 1786.0 \\
\hline $\mathrm{F}_{0} \mathrm{P}_{30} \mathrm{~S}_{20}$ & 7.9 & 32.1 & 1.7 & 13.0 & 76.6 & 20.6 & 2608.3 \\
\hline $\mathrm{F}_{0} \mathrm{P}_{60} \mathrm{~S}_{20}$ & 8.3 & 34.9 & 1.8 & 13.2 & 81.6 & 20.9 & 2834.0 \\
\hline $\mathrm{F}_{1} \mathrm{P}_{0} \mathrm{~S}_{0}$ & 6.5 & 22.3 & 1.5 & 11.8 & 56.5 & 19.5 & 1666.0 \\
\hline $\mathrm{F}_{1} \mathrm{P}_{30} \mathrm{~S}_{0}$ & 7.3 & 30.6 & 1.7 & 12.9 & 69.3 & 20.2 & 2516.0 \\
\hline $\mathrm{F}_{1} \mathrm{P}_{60} \mathrm{~S}_{0}$ & 7.6 & 32.0 & 1.7 & 13.0 & 75.0 & 20.4 & 2600.7 \\
\hline $\mathrm{F}_{1} \mathrm{P}_{0} \mathrm{~S}_{20}$ & 7.0 & 27.2 & 1.6 & 12.6 & 62.6 & 19.9 & 2171.0 \\
\hline $\mathrm{F}_{1} \mathrm{P}_{30} \mathrm{~S}_{20}$ & 8.4 & 34.7 & 1.8 & 13.1 & 80.3 & 20.8 & 2815.3 \\
\hline $\mathrm{F}_{1} \mathrm{P}_{60} \mathrm{~S}_{20}$ & 8.9 & 36.5 & 1.8 & 13.4 & 83.1 & 21.1 & 2979.3 \\
\hline $\operatorname{SEm}( \pm)$ & 0.3 & 1.6 & 0.4 & 0.2 & 3.1 & 0.3 & 83.4 \\
\hline $\mathrm{CD}(\mathrm{P}=0.05)$ & 0.9 & 4.5 & NS & 0.6 & 9.2 & 0.9 & 244.6 \\
\hline
\end{tabular}

improved the protein content by $5.6 \%$ and application of $20 \mathrm{~kg} \mathrm{ha}^{-1}$ sulphur significantly improved the protein content by $3 \%$ irrespective of FYM and phosphorus. Application of $60 \mathrm{~kg} \mathrm{ha}^{-1}$ phosphorus and $20 \mathrm{~kg} \mathrm{ha}^{-1}$ sulphur in Farm yard manure treated plot $\left(5 \mathrm{t} \mathrm{ha}^{-1}\right)$ increased the protein content of chickpea seed by $10.5 \%$ over control. This result was in conformity with the findings of Patel et al. (2014). They also found that $\mathrm{S}$ and $\mathrm{P}$ management in chickpea had significant influence on protein content of grain as increasing protein content in respective treatment was mainly on account of significant increase in nitrogen content and also more absorption of sulphur by chickpea grain. Since, both nutrients are closely linked with protein metabolism 
Table 5. Effect of FYM on nutrient uptake in chickpea (Pooled data of 3 years).

\begin{tabular}{|c|c|c|c|c|}
\hline Treatment & $\begin{array}{l}\text { Total N Uptake } \\
\left(\mathrm{kg} \mathrm{ha}^{-1}\right)\end{array}$ & $\begin{array}{l}\text { Available P Uptake } \\
\left(\mathrm{kg} \mathrm{ha}^{-1}\right)\end{array}$ & $\begin{array}{l}\begin{array}{l}\text { Available K Up- } \\
\text { take }\left(\mathrm{kg} \mathrm{ha}^{-1}\right)\end{array} \\
\end{array}$ & $\begin{array}{l}\text { Available S Uptake } \\
\left(\mathrm{kg} \mathrm{ha}^{-1}\right)\end{array}$ \\
\hline $\mathrm{F}_{0}$ & 73.2 & 19.5 & 52.9 & 10.6 \\
\hline $\mathrm{F}_{1}$ & 80.2 & 21.4 & 57.9 & 11.7 \\
\hline $\operatorname{SEm}( \pm)$ & 0.9 & 0.1 & 0.4 & 0.1 \\
\hline $\mathrm{CD}(\mathrm{P}=0.05)$ & 2.5 & 0.3 & 1.2 & 0.2 \\
\hline
\end{tabular}

Table 6. Effect of phosphorus on nutrient uptake in chickpea (Pooled data of 3 years).

\begin{tabular}{|c|c|c|c|c|}
\hline Treatment & $\begin{array}{l}\text { Total N Uptake } \\
\left(\mathrm{kg} \mathrm{ha}^{-1}\right)\end{array}$ & Available P Uptake $\left(\mathrm{kg} \mathrm{ha}^{-1}\right)$ & $\begin{array}{l}\text { Available K Uptake } \\
\left(\mathrm{kg} \mathrm{ha}^{-1}\right)\end{array}$ & $\begin{array}{l}\text { Available S Uptake } \\
\left(\mathrm{kg} \mathrm{ha}^{-1}\right)\end{array}$ \\
\hline $\mathrm{P}_{0}$ & 55.7 & 15.2 & 39.8 & 8.3 \\
\hline $\mathrm{P}_{30}$ & 83.7 & 22.2 & 60.6 & 12.1 \\
\hline $\mathrm{P}_{60}$ & 90.6 & 24.0 & 65.8 & 13.0 \\
\hline $\operatorname{SEm}( \pm)$ & 1.2 & 0.1 & 0.5 & 0.1 \\
\hline $\mathrm{CD}(\mathrm{P}=0.05)$ & 3.6 & 0.4 & 1.6 & 0.3 \\
\hline
\end{tabular}

Table 7. Effect of sulphur on nutrient uptake in chickpea (Pooled data of 3 years).

\begin{tabular}{lllll}
\hline Treatment & $\begin{array}{l}\text { Total N Uptake } \\
\left(\mathbf{k g ~ h a}^{-\mathbf{1}}\right)\end{array}$ & $\begin{array}{l}\text { Available P Uptake } \\
\left(\mathbf{k g ~ h a}^{-\mathbf{1}}\right)\end{array}$ & $\begin{array}{l}\text { Available K Uptake } \\
\left.\mathbf{( k g ~ h a ~}^{-1}\right)\end{array}$ & $\begin{array}{l}\text { Available S Uptake } \\
\left(\mathbf{k g ~ h a}^{\mathbf{- 1}}\right)\end{array}$ \\
\hline $\mathrm{S}_{0}$ & 69.9 & 18.8 & 50.3 & 10.1 \\
$\mathrm{~S}_{20}$ & 83.4 & 22.1 & 60.5 & 12.1 \\
$\mathrm{SEm}( \pm)$ & 0.9 & 0.1 & 0.4 & 0.1 \\
$\mathrm{CD}(\mathrm{P}=0.05)$ & 2.5 & 0.3 & 1.2 & 0.2 \\
\hline
\end{tabular}

Table 8. Interaction effect of FYM, phosphorus and sulphur on nutrient uptake in chickpea (Pooled data of 3 years).

\begin{tabular}{|c|c|c|c|c|}
\hline Treatment & $\begin{array}{l}\text { Total N Uptake } \\
\left(\mathrm{kg} \mathrm{ha}^{-1}\right)\end{array}$ & $\begin{array}{l}\text { Available P Uptake } \\
\left(\mathrm{kg} \mathrm{ha}^{-1}\right)\end{array}$ & $\begin{array}{l}\text { Available K Uptake } \\
\left(\mathrm{kg} \mathrm{ha}^{-1}\right)\end{array}$ & $\begin{array}{l}\text { Available S Uptake } \\
\left(\mathrm{kg} \mathrm{ha}^{-1}\right)\end{array}$ \\
\hline $\mathrm{F}_{0} \mathrm{P}_{0} \mathrm{~S}_{0}$ & 45.5 & 12.6 & 32.7 & 6.8 \\
\hline $\mathrm{F}_{0} \mathrm{P}_{30} \mathrm{~S}_{0}$ & 73.8 & 19.8 & 53.0 & 10.6 \\
\hline $\mathrm{F}_{0} \mathrm{P}_{60} \mathrm{~S}_{0}$ & 82.2 & 21.9 & 59.4 & 11.6 \\
\hline $\mathrm{F}_{0} \mathrm{P}_{0} \mathrm{~S}_{20}$ & 56.4 & 15.2 & 40.2 & 8.4 \\
\hline $\mathrm{F}_{0} \mathrm{P}_{30} \mathrm{~S}_{20}$ & 86.1 & 22.7 & 62.6 & 12.5 \\
\hline $\mathrm{F}_{0} \mathrm{P}_{60} \mathrm{~S}_{20}$ & 94.9 & 24.9 & 69.4 & 13.6 \\
\hline $\mathrm{F}_{1} \mathrm{P}_{0} \mathrm{~S}_{0}$ & 51.9 & 14.2 & 36.9 & 7.7 \\
\hline $\mathrm{F}_{1} \mathrm{P}_{30} \mathrm{~S}_{0}$ & 81.3 & 21.6 & 58.4 & 11.8 \\
\hline $\mathrm{F}_{1} \mathrm{P}_{60} \mathrm{~S}_{0}$ & 84.8 & 22.6 & 61.4 & 12.2 \\
\hline $\mathrm{F}_{1} \mathrm{P}_{0} \mathrm{~S}_{20}$ & 69.0 & 18.7 & 49.5 & 10.2 \\
\hline $\mathrm{F}_{1} \mathrm{P}_{30} \mathrm{~S}_{20}$ & 93.5 & 24.5 & 68.4 & 13.5 \\
\hline $\mathrm{F}_{1} \mathrm{P}_{60} \mathrm{~S}_{20}$ & 100.4 & 26.5 & 72.9 & 14.6 \\
\hline S.Em $( \pm)$ & 1.7 & 0.2 & 0.8 & 0.1 \\
\hline $\mathrm{CD}(\mathrm{P}=0.05)$ & 5.0 & 0.6 & 2.3 & 0.4 \\
\hline
\end{tabular}

and their relationship was synergistic.

Effect on nodulation: Active nodule number at 50\% flowering stage of crop growth was significantly influenced by different levels of FYM, phosphorus, sulphur and interaction effect of FYM, P and S (Tables 1-4). Application of FYM@ $9 \mathrm{t} \mathrm{ha}^{-1}$ increased the nodule no. by $5.5 \%$. Application of phosphorus $60 \mathrm{~kg} \mathrm{ha}^{-1}$ increased the nodule no. by $6.2 \%$ over application of phosphorus $30 \mathrm{~kg} \mathrm{ha}^{-1}$ and $34.8 \%$ over it's non application. These results corroborated with the findings of Singh et al. (2010). They reported that FYM improved dry weight of nodules significantly by $14.1 \%$ over no FYM application. Application of $20 \mathrm{~kg} \mathrm{P}^{-1}$ and 40 $\mathrm{kg} \mathrm{P} \mathrm{ha}^{-1}$ improved nodulation significantly over no application of phosphorus. Similarly Basir et al. (2008) noted maximum number of nodules per plant in those treatments which received nutrition at the rate of $15 \mathrm{t}$ FYM ha ${ }^{-1}$ and $60 \mathrm{~kg} \mathrm{P} \mathrm{ha}^{-1}$ while minimum number of nodules per plant was recorded from plots where no FYM and phosphorus was applied. Application of sulphur $20 \mathrm{~kg} \mathrm{ha}^{-1}$ increased the nodule no. by $14.4 \%$. Similar results were also reported by Ganeshamurthy and Reddy (2000). In case of interaction effect application of $60 \mathrm{~kg} \mathrm{ha}^{-1}$ phosphorus and $20 \mathrm{~kg} \mathrm{ha}^{-1}$ sulphur in Farm yard manure treated plot $\left(5 \mathrm{t} \mathrm{ha}^{-1}\right)$ recorded highest nodule number ( 83.1 nos.) and it increased the nodule no. by $62.3 \%$ over control plot. Similarly Islam and Ali (2009) reported that application of P (40 and $80 \mathrm{~kg} \mathrm{ha}^{-1}$ ) increased $\mathrm{N}$ fixation by $26 \%$ and $40 \%$, similarly, an increase of $15 \%$ and $19 \%$ was recorded with S application (15 and $30 \mathrm{~kg} \mathrm{ha}^{-1}$ ).Ganeshamurthy et al. (2005) also recorded significantly higher nodule number in green gram due to combined application of phosphorus and sulphur.

Effect on nutrient uptake: Experimental results revealed that the higher uptake of nutrients $(\mathrm{N}, \mathrm{P}, \mathrm{K} \&$ S) by chickpea was the resultant of higher yield (Tables 5-8). Nutrient uptake of chickpea was significantly influenced by FYM, P, S and interaction of these three factors. Application of $5 \mathrm{t} \mathrm{ha}^{-1}$ FYM increased the 
uptake of $\mathrm{N}$ by $9.6 \%$, P by $9.7 \%$, K by $9.5 \%$ and $\mathrm{S}$ by $10.4 \%$. Phosphorus application with higher rate significantly improved the nutrient uptake (N, P, K and S) by chickpea crop. Application of phosphorus $60 \mathrm{~kg}$ ha $^{-1}$ increased the uptake of $\mathrm{N}$ by $8.2 \%$, P by $8.1 \%, \mathrm{~K}$ by $8.6 \%$ and $\mathrm{S}$ by $7.4 \%$.over application of phosphorus $30 \mathrm{~kg} \mathrm{ha}^{-1}$ and increased the uptake of $\mathrm{N}$ by $62.7 \%, \mathrm{P}$ by $57.9 \%$, K by $65.3 \%$ and $\mathrm{S}$ by $56.6 \%$.over it's non application. Nutrient uptake (N, P, K and S) were significantly improved with $\mathrm{S}$ application $20 \mathrm{~kg} \mathrm{ha}^{-1}$. Application of sulphur $20 \mathrm{~kg} \mathrm{ha}^{-1}$ increased the uptake of $\mathrm{N}$ by $19.3 \%$, P by $17.6 \%$, K by $20.3 \%$ and $\mathrm{S}$ by $19.8 \%$. In case of interaction effects application of 60 $\mathrm{kg} \mathrm{ha}^{-1}$ phosphorus and $20 \mathrm{~kg} \mathrm{ha}^{-1}$ sulphur in Farm yard manure treated plot $\left(5 \mathrm{t} \mathrm{ha}^{-1}\right)$ recorded highest nutrient uptake $\left(100.4 \mathrm{~kg} \mathrm{~N} \mathrm{ha}^{-1}, 26.5 \mathrm{~kg} \mathrm{P}_{2} 0_{5} \mathrm{ha}^{-1}, 72.9 \mathrm{~kg} \mathrm{~K}_{2} 0\right.$ $\mathrm{ha}^{-1}$ and $14.6 \mathrm{~kg} \mathrm{~S} \mathrm{ha}^{-1}$ ) and lowest uptake was found with control plot. Similar findings were also reported by Islam and Ali (2009). They reported that nutrient uptake $(\mathrm{N}, \mathrm{P}$ and $\mathrm{S})$ in chick pea increased significantly with the application of both $\mathrm{P}$ and S. Singh et al. (2004) also recorded highest uptake of N,P,K and S with $60 \mathrm{~kg} \mathrm{P} \mathrm{ha}^{-1}$ and $40 \mathrm{~kg} \mathrm{~S}^{-1}$.

\section{Conclusion}

It can be concluded that application of $60 \mathrm{~kg} \mathrm{ha}^{-1}$ phosphorus and $20 \mathrm{~kg} \mathrm{ha}^{-1}$ sulphur in Farm yard manure treated plot $\left(5 \mathrm{tha}^{-1}\right)$ along with recommended dose of nitrogen and potassium proved to be the best treatment combination for chickpea in enhancing the productivity, protein content, nodulation and nutrient uptake by the crop in a sulphur deficient soil of new alluvial zone of West Bengal.

\section{REFERENCES}

Ahmad, A., and Abdin, M.Z. (2000). Photosynthesis and its related physiological variables in the leaves of Brassica. genotypes as influenced by sulphur fertilization. Physiol. Plantarum. 110: 144-149.

Basir, A., Shah, Z., Naeem, M., Bakht, J. and Khan, Z.H. (2008). Effect of phosphorus and farm yard manure on agronomic traits of chickpea (Cicer arietinum L.). Sarhad J. Agric. 24 (4): 567-572.

Biswas, B.C., Sarkar, M.C., Tanwar, S.P.S. and Das, S. (2004). Sulphur deficiency in soil and crop response to fertilizer sulphur in India. Fertilizer News . 49 (10): 13-33.

Claro-Cortes, P., Nunez-Escobar, R. and Etchevers-Barra, J.D. (2002). Green house grown maize respose to sulphur in two soils of Puebla state Mexico. Agrociencia. 36: 633636.

Daramola, D.S., Adebayo, A. and Odeyemi, O. (1982). Effect of herbicide application on legume Rhizobium symbiosis with and without starter nitrogen. Turrialba. 32: 315-320.

Das, S., Nath, R. and Chakraborty, A. (2015). Performance of chickpea (Cicer arietinum L.) cultivars and estimation of economic optimum doses of phosphorus in an Alfisol of West Bengal. Journal Crop and Weed. 11(Special Issue):113-117.

Dotania, M.L., Pingoliya, K.K., Lata, M., Verma, R., Regar, K.L., Deewan P. and Dotania, C.K. (2014). Role of phos- phorus in chickpea (Cicer arietinum L.) production. African J. of Agric. Res. 9(51): 3736-3743.

Ganeshamurthy, A.N. and Reddy, K.S. (2000). Effect of integrated use of farm yard manure and sulphur in soybean and wheat cropping system on nodulation, dry matter production and chlorophyll content of soybean on swell shrink soils in Central India. J. Agron. Crop Sci. 185: 191 $-197$.

Ganeshamurthy, A.N., Srinivasarao, C.H., Ali, M. and Singh, B.B. (2005). Balanced fertilization of Greengram cultivars on a multi-nutrient deficient typic Ustochrept soil. Indian Journal of Agricultural Sciences. 75 (4) : 192-196.

Ghosh, S.K. , Mukhopadhyay, A.K. and Sarkar, M. (2002). Status and profile distribution of forms of sulphur in some established soil series belonging to inceptisols of West Bengal. Indian Agric. 46 (3 and 4): 147-152.

Islam, M. and Ali, S. (2009). Effect of integrated application of sulphur and phosphorus on nitrogen fixation and nutrient uptake by Chickpea (Cicer arietinum L.). Agrociencia. 43 (8).

Morris, R.J. (1988). Sulphur in world Agriculture. Proceedings of TSI-FAI Symposium (Sulphur in Indian Agriculture ) $\mathrm{KS} / 1$ (1-14).

Olivera, M., Tejera, N., Iribarne, C., Ocana, A. and Lluch, C. (2004). Growth, nitrogen fixation and ammonium assimilation in common bean (Phaseolus vulgaris): effect of 642phosphorus. Physiologia Plantarum.121: 498-505.

Patel, H.K., Patel, P.M., Suthar, J.V and Patel, M.R. (2014).Yield, quality and post harvest nutrient status of chick pea as influenced by application of sulphur and phosphorus fertilizer management. Int. J. of Scientific and Research Publication. 4(7): 1-3.

Patil, S.V., Halikatti, S.I. , Hiremath, S.M. , Babalad, H.B. , Sreenivasa, M.N. , Hebsur, N.S. and Somanagouda, G. (2011). Effect of organic manures and rock phosphate on growth and yield of chickpea (Cicer arietinum L.) in vertisols. Karnataka J. Agric. Sci. 24 (5) : 636-638.

Scherer, H.W. , Pacyna, S., Spoth, K and Schulz, M. (2008). Low levels of ferredoxin, ATP and leghemoglobin contribute to limited $\mathrm{N}$ fixation of peas (Pisum sativum L.) and alfalfa (Medicago sativa $\mathrm{L}$.) under $\mathrm{S}$ deficiency conditions. Biol. Fértil. Soils. 44: 909-916.

Schulze, J., Temple, G., Temple, S.J., Beschow, H. and Vance, C.P. (2006). Nitrogen fixation by white lupin under phosphorus deficiency. Ann. Bot., 98: 731-40.

Singh, G., Sekhon, H.S. and Kaur, H. (2012). Effect of FYM, Vermicompost and chemical nutrients on growth and yield of chickpea (Cicer arietinum L.). Int. J. of Agril. Res.7(2): 93-99.

Singh, G., Sekhon, H.S., Ram, H. and Sharma, P. (2010). Effect of farmyard manure, phosphorus and phosphate solubilizing bacteria on nodulation, growth and yield of kabuli chickpea. Journal of Food Legumes. 23 (3 and 4): 226229.

Singh, S., Saini, S.S. and Singh, B.P. (2004). Effect of irrigation, sulphur and seed inoculation on growth, yield and sulphur uptake of chickpea (Cicer arietinum) under latesown conditions. Indian Journal of Agronomy. 49(1): 5759.

Srinivasarao, Ch., Ganeshamurthy, A.N., Ali, M., Singh, R.N. and Singh, K.K. (2004). Sulphur fractions, distribution and their relationship with soil properties in different soil types of major pulse growing regions of India. Commun. Soil Sci. Plant Anal. 35 (19 \& 20): 2757-2769. 